\title{
Production Constraints in Cultivation of Pulp Wood Trees in Tamil Nadu, India
}

\author{
D. Dilipkumar ${ }^{1 *}$ and R. Venkatram ${ }^{2}$ \\ ${ }^{1}$ Department of Agricultural and Rural Management, Tamil Nadu Agricultural University, \\ Coimbatore, Tamil Nadu, India \\ ${ }^{2}$ Planning and Monitoring, Tamil Nadu Agricultural University, Coimbatore, \\ Tamil Nadu, India \\ *Corresponding author
}

\section{A B S T R A C T}

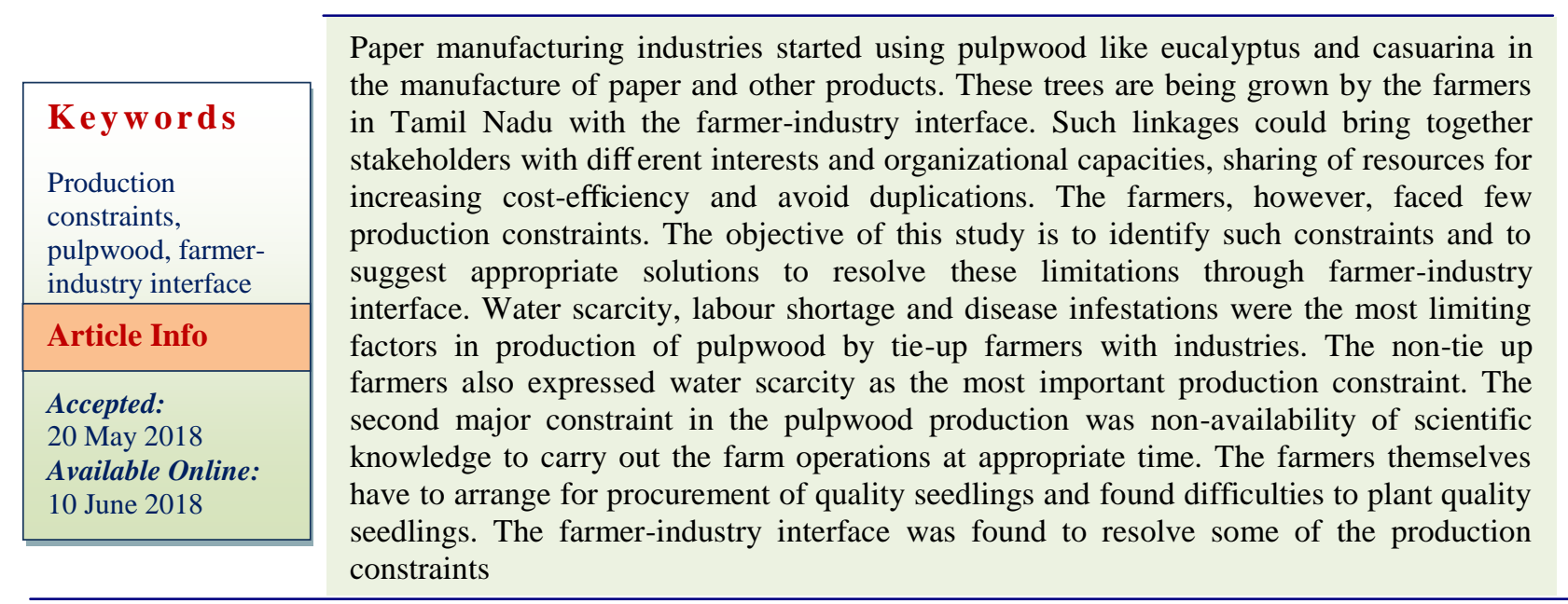

\section{Introduction}

Most of the traditional paper industries dependent on bamboo as the basic raw material. The shortage of this raw material is one of the chronic problems in many of the paper manufacturing units. This has been further accentuated by the stricter ecological regulation and restriction in felling of trees. Hence, bagasse, an industrial waste in the manufacture of sugar, was found as an alternative to bamboo and used in paper and pulp industries. Later, these industries started using pulpwood like eucalyptus and casuarina in the manufacture of paper and other products. Further, by establishing pulpwood raw material outside the forest area, the same amount of natural forest remains protected without disturbance for pulpwood and firewood.

Eucalyptus and Casuarina are the major pulpwood trees grown by the farmers in Tamil Nadu with the farmer-industry interface. Such linkages could bring together stakeholders with diff erent interests and organizational 
capacities, sharing of resources for increasing cost-efficiency and avoid duplications (Asaah and Tsobeng, 2013). Since the technologies to be transferred needed more capacity building in business development, the interface could also respond well to such needs. In some cases, such interventions could enhance adoption and create impact through research/innovations and thus expand potentials to raise productivity and sustainability of various initiatives. The farmers, however, faced few production constraints. The objective of this study is to identify such constraints and to suggest appropriate solutions to resolve these limitations through farmer-industry interface.

\section{Materials and Methods}

There are seven agro-climatic zones in Tamil Nadu. Among these zones, the farmers in Cauvery Delta zone were found to cultivate the eucalyptus and casuarinas on commercial basis. The cultivation is done both with tie-up arrangements with paper industries and nontie up arrangements. Among the eight districts, based in the Cauvery Delta Zone, based on the proportionate area under pulpwood cultivation, two districts namely Cuddalore and Pudukottai were selected for the study.

In the next stage of sampling, using the same criteria of area coverage under pulp wood trees, three blocks were selected from each district. In Cuddalore district, three blocks namely Panruti, Kurunchipadi, Kattumanarkovil were selected and in Pudukkotai district, three blocks namely Alangudi, Illupur, Gandarvakottai were selected. In each block, three villages were selected at random and from each selected village, ten farmers who had entered a contract with the two major players for supply of pulp wood tress (Tie-up Farmers) were selected randomly from the list obtained from these firms. Thus, 90 farmers were selected from each district for each pulpwood tree. In addition to these respondents, 30 non-tie up farmers, who did not have any prearrangement for selling the pulpwood to the identified industries, were also selected from each district. The data from the sample respondents were collected through personal interview method during the months of December 2016 to May 2017.

To identify the production constraints in eucalyptus and casuarina production, Garrett's ranking technique was used. The respondents were asked to rank the problems in eucalyptus and casuarina pulp wood production.

\section{Results and Discussion}

The pulpwood tree growers in the study area faced production constraints. Eight major production constraints were identified and these constraints were ranked and based on Garrett's ranking technique the ranks were ordered as per the mean score values.

\section{Constraints in Eucalyptus cultivation}

The various constraints faced by the eucalyptus cultivators are presented in Table 1.

It could be seen from the Table 1 that among the eight production constraints, majority of the farmers expressed that the water scarcity was the most serious constraint followed by labour shortage and disease infestation. The shortage of labour was mainly due to diversion of labour for Mahatma Gandhi National Rural Employment Guarantee Scheme. Though the farmers take adequate precautions for control of disease, the cost incurred on plant protection chemicals in the overall cost of cultivation is predominant. The production constraints faced by the non-tie up farmers along with the ranks are presented in Table 2. 
Table.1 Production Constraints in eucalyptus (Tie up farmers)

\begin{tabular}{|c|l|r|c|}
\hline S. No. & \multicolumn{1}{|c|}{ Problems and constraints } & Mean Score & Rank \\
\hline $\mathbf{1 .}$ & Water scarcity & 78.4 & I \\
\hline $\mathbf{2}$. & Shortage of labour & 78.0 & II \\
\hline $\mathbf{3 .}$ & Disease & 71.2 & III \\
\hline $\mathbf{4 .}$ & High input cost & 71.0 & VIII \\
\hline $\mathbf{5 .}$ & Appropriate scientific knowledge & 70.6 & IV \\
\hline $\mathbf{6 .}$ & Lack of finance & 69.0 & V \\
\hline $\mathbf{7 .}$ & Non-availability of seedling & 68.8 & VI \\
\hline $\mathbf{8 .}$ & Quality seedlings & 68.6 & VII \\
\hline
\end{tabular}

Table.2 Production constraints in eucalyptus (Non-Tie up farmers)

\begin{tabular}{|c|}
\hline S. No. \\
\hline 1. \\
\hline 2. \\
\hline 3. \\
\hline 4. \\
\hline 5. \\
\hline 6. \\
\hline 7. \\
\hline
\end{tabular}

\section{Problems and constrains}

Water scarcity

Appropriate scientific knowledge

Quality seedlings

Lack of finance

Shortage of labour

Disease

Non availability of seedling

High input cost

\begin{tabular}{|c|c|}
\hline Mean Score & Rank \\
\hline 80.0 & I \\
\hline 75.0 & II \\
\hline 73.3 & III \\
\hline 71.2 & IV \\
\hline 68.1 & V \\
\hline 66.3 & VI \\
\hline 65.4 & VII \\
\hline 64.6 & VIII \\
\hline
\end{tabular}

Table.3 Production constraints in Casuarina (Tie-up farmers)

\begin{tabular}{|c|}
\hline S. No. \\
\hline 1. \\
\hline 2. \\
\hline 3. \\
\hline 4. \\
\hline 5. \\
\hline 6. \\
\hline 7. \\
\hline 8. \\
\hline
\end{tabular}

\section{Problems and constrains}

Water scarcity

Shortage of labour

Disease

Non availability of seedlings

Lack of finance

Quality seedlings

High input cost

Appropriate scientific knowledge

\begin{tabular}{|c|c|}
\hline Mean Score & Rank \\
\hline 77.8 & I \\
\hline 77.0 & II \\
\hline 72.4 & III \\
\hline 70.8 & IV \\
\hline 69.4 & V \\
\hline 68.4 & VI \\
\hline 68.2 & VII \\
\hline 68.0 & VIII \\
\hline
\end{tabular}

Table.4 Production constraints in casuarina (Non-tie up farmers)

\begin{tabular}{|c|}
\hline S. No. \\
\hline 1. \\
\hline 2. \\
\hline 3. \\
\hline 4. \\
\hline 5. \\
\hline 6. \\
\hline 7. \\
\hline 8. \\
\hline
\end{tabular}

\section{Problems and constrains}

Water scarcity

Appropriate scientific knowledge

Non availability of seedling

Lack of finance

Disease

Shortage of labour

Quality seedling

High input cost

\begin{tabular}{|r|c|}
\hline Mean Score & Rank \\
\hline 79.2 & I \\
\hline 78.0 & II \\
\hline 73.0 & III \\
\hline 71.4 & IV \\
\hline 70.2 & V \\
\hline 69.2 & VI \\
\hline 69.1 & VII \\
\hline 65.2 & VIII \\
\hline
\end{tabular}


It could be seen from the Table 2 that majority of the producers expressed water scarcity as the most important production constraint. The second major constraint in the pulpwood production was non-availability of scientific knowledge to carry out the farm operations at appropriate time. Though the non-tie up farmers could avail the technical support from officials of Government Department, the farmers expressed their inability to access such support. The farmers themselves have to arrange for procurement of quality seedlings and found difficulties to plant quality seedlings. The fourth major constraint was lack of finance. The long duration tree crops like eucalyptus have longer gestation period to realize the output (yield) and the sample farmers expressed the difficulty in getting adequate credit and at right time

\section{Constraints in Casuarina cultivation}

The problems/constraints encountered by the farmers in casuarina cultivation are analyzed and the results are presented in Tables 3

It could be seen from the Table 3 that among the eight production constraints, majority of the farmers expressed that the water scarcity as the most important constraint followed by labour shortage and disease infestation. The shortage of labour was mainly due to diversion of labour for government sponsored programmes like Mahatma Gandhi National Rural Employment Guarantee Scheme. Though the farmers take adequate precautions for control of disease, the cost incurred on plant protection chemicals in the overall cost of cultivation is predominant. The production constraints faced by the non-tie up farmers along with the ranks are presented in Table 4.

It could be seen from the Table 4 that majority of the producers expressed water scarcity as the most important production constraint. The second major constraint in the pulpwood production was non-availability of scientific knowledge to carry out the farm operations at appropriate time. The farmers themselves have to arrange for procurement of quality seedlings and found difficulties to plant quality seedlings. The fourth major constraint was lack of finance. The long duration tree crops like casuarina have longer gestation period to realize the output (yield) and the sample farmers expressed the difficulty in getting adequate credit and at right time.

The eucalyptus tree growers in the study area expressed few monetary and non-monetary benefits by entering into a contract with paper industries. Among the various benefits enjoyed by the tie-up farmers, the producers expressed that the paper industries made no delay in payment and ensured payment. This was considered as one of the most important benefits by entering a contract.

The second major benefit expressed was uniform price. The farmers felt that compared to short-term investment, the long-term investment and longer waiting time had its own benefit as they could get better return on investment especially in marginal lands. The other benefits realized were assured availability of inputs including credit with reasonable interest rate, insurance cover and premium price as against other means of disposal of pulpwood.

The non-monetary benefits enjoyed by the tie up farmers are the technical service provided by the industry, supply of quality planting materials, creation of awareness among the farmers in ensuring better quality of pulpwood and risk minimization and access to technology.

The farmer-industry interface has helped the tie-up farmers to receive quality seedlings, 
scientific knowledge and financial support as against the non-tie up farmers who faced these as the major production constraints. Water scarcity was expressed as the most serious limitations in cultivation of pulpwood trees by the both the farmer groups. Since these tress are long-duration crops, irrigation has to be done more frequently. However, the total water requirement is comparatively less than cultivation of annual crops. The farmers also had limited options to cultivate annual crops in these marginal lands other than pulpwood trees.

\section{References}

Asaah and Tsobeng, 2013 Public--- Private partnerships for sustainable agriculture and business development: Allanblackia species as a case study.

Garrett, H. E. and Woodworth, R. S. (1969). "Statistics in Psychology and Education", Vakils Feffer and Simons Pvt. Ltd., Bombay, p.329.

Mahmood Ahmad (2012), "An Empirical study on measurement of performance through TQM in Pakistan Aviation Manufacturing Industry". International Journal of Quality and Reliability Management. Vol, 31, Issue 6.

Tewari, D.D. (2008), Valuation of NonTimber Forest Products (NTFPs): Models, Problems, and Issue. Journal of Sustainable Forestry 11(4):47-68.

www.sbp.org.in

www.tnpl.plantation.in

\section{How to cite this article:}

Dilipkumar D. and Venkatram R. 2018. Production Constraints in Cultivation of Pulp Wood Trees in Tamil Nadu, India. Int.J.Curr.Microbiol.App.Sci. 7(06): 2271-2275. doi: https://doi.org/10.20546/ijcmas.2018.706.271 